\title{
Acute Thyrotoxicosis Induced Reversible Cardiomyopathy in an Adult Patient
}

\section{Erişkin Bir Hastada Akut Tirotoksikoza Bağlı Reversibil Kardiyomiyopati}

\author{
• Vedat Çiçek, • Tufan Çınar, • Murat Selçuk, • Ahmet L. Orhan \\ University of Health Sciences Turkey, Sultan 2. Abdülhamid Han Training and Research Hospital, Clinic of Cardiology, İstanbul, Turkey
}

In most cases, congestive heart failure (CHF) usually develops secondary to coronary artery disease or valvular heart disease. However, acute thyrotoxicosis might be an infrequent cause of CHF in some patients. In this report, we presented a case of adult patient without a previous diagnosis of chronic disorder, who was admitted to the emergency department with CHF and newly developed atrial fibrillation. In addition, in this case, we reported that acute thyrotoxicosis could cause severe but reversible LV dysfunction in relatively young individuals.

Keywords: Thyrotoxicosis, congestive heart failure, reversible

Çoğu olgularda, konjestif kalp yetmezliği (KKY) genellikle koroner arter hastalığına veya kalp kapak hastalığına ikincil olarak gelişir. Bununla birlikte, akut tirotoksikoz, bazı hastalarda KKY'nin seyrek bir nedeni olabilir. Bu olguda, daha önce kronik hastalık tanısı olmayan, KKY ve yeni gelişen atriyal fibrilasyon ile acil servise başvuran erişkin bir hastayı sunduk. Ek olarak, bu olguda, akut tirotoksikozun nispeten genç bireylerde ciddi ancak geri dönüşlü sol ventrikül disfonksiyonuna neden olabileceğini gösterdik. Anahtar Kelimeler: Tirotoksikoz, konjestif kalp yetmezliği, geri dönüşümlü

\section{Introduction}

Congestive heart failure (CHF) is a medical condition that occurs as a result of coronary artery disease or valvular heart disease. On the other hand, a rare cause of CHF might be a thyrotoxicosis disorder, which can be reversible with an appropriate treatment. Initially, patients with thyrotoxicosis develop exercise intolerance due to elevated cardiac output (1). However, if thyrotoxicosis is not diagnosed and treated properly, patients may develop a severe systolic dysfunction in the later stages of the disease. This condition is commonly observed in elderly patients with pre-existing heart disease (2). In this report, we presented a case of an adult patient without a previous diagnosis of chronic disorder, who was admitted to the emergency department (ED) with CHF and newly developed atrial fibrillation (AF). Moreover, this case highlights that systolic heart failure can be reversible in some patients with thyrotoxicosis.

\section{Case Report}

A 49-year-old male patient presented to our ED with the complaints of palpitation and progressive shortness of breath. Medical records were inconclusive. Upon physical examination, it was noted that the patient was dyspneic and sweaty. The patient's blood pressure was $93 / 47 \mathrm{mmHg}$ with heart rate of 132 beats/min, and there was $3(+)$ bilateral pretibial edema. On lung examination, bilateral diffuse rales were heard. A 12-lead electrocardiography (ECG) obtained in the ED revealed an AF (Figure 1A). A posterior-anterior chest scan was performed, providing an enlargement of the cardiothoracic ratio and bilateral pleural effusion (Figure 1B). On laboratory analysis, brain natriuretic peptide level was 1373,2 $\mathrm{pg} / \mathrm{mL}$. The patient was admitted to cardiac intensive care unit with a pre-diagnosis of acute HF. Bedside transthoracic echocardiography (TTE) was performed, revealing a left ventricle ejection fraction (LVEF) of $23 \%$ with mild mitral regurgitation. Low dose inotrope infusion therapy was initiated in addition to the IV diuretic therapy. The patient became hemodynamically stable after the treatment. Thyroid stimulating hormone (TSH) level obtained next day following admission was significantly depressed $(<0.0025 \mathrm{ulU} / \mathrm{mL}$ ). The thyroid ultrasonography findings were compatible with Basedow-Graves' disease. Afterward, propylthiouracil (PTU) treatment was initiated by the endocrinology department. Coronary angiography (CAG) was not planned because the

Address for Correspondence: Tufan Çınar, University of Health Sciences Turkey, Sultan 2. Abdülhamid Han Training and Research Hospital, Clinic of Cardiology, İstanbul, Turkey Phone: +90 5442300520 E-mail: drtufancinar@gmail.com ORCID ID: orcid.org/0000-0001-8188-5020

Received: 11.07.2021 Accepted: 07.08.2021 
patient had recently undergone CAG in another center, which demonstrated normal coronary arteries. The patient's condition was progressively improved following days, and he was discharged with beta-blocker, low-molecular-weight heparin, diuretic, angiotensinogen converting enzyme (ACE) inhibitor, mineralocorticoid-receptor antagonists, and PTU treatment. The patient's TSH level $(0.1403 \mathrm{ulU} / \mathrm{mL})$ was within the normal range on one-month outpatient clinic visit. The control TTE showed an improvement of LVEF at a rate of 38\% (Figure 2A). Moreover, the patient's ECG was returned to normal sinus rhythm spontaneously and his exercise capacity was significantly improved. Because the patient's $\mathrm{CHA}_{2} \mathrm{DS}_{2}$ VASc score was " 0 " and AF was thought to be reversible, anticoagulant treatment was discontinued. On the fifth-month follow-up, the LVEF was $65 \%$ on TTE examination (Figure 2B). Moreover, the patient' exercise capacity was over 10 Mets.

\section{Discussion}

Thyroid hormone disorders are frequently encountered in clinical practice, and their prevalence increases with age. Thyrotoxicosis is a clinical condition characterized by a suppression of TSH levels and increased peripheral T4 and /or T3 levels. The most common cause is Basedow-Graves' disease that occurs due to thyroid hormone-releasing auto immune antibodies (3). Thyrotoxicosis can affect the cardiovascular system by both decreasing systemic vascular resistance and increasing heart rate, preload, and cardiac output. All of these changes can develop due to vascular smooth muscle relaxation, increase of endothelium-induced nitric oxide release, activation of the renin-angiotensin system, and increased erythropoietin secretion (4). Also, these pathologic mechanisms can lead to HF secondary to elevated cardiac output in patients with thyrotoxicosis. Cardiac output is $50-300 \%$ higher in hyperthyroid cases than in individuals with normal thyroid function (5). This causes a high-output HF characterized by blood pumping at a rate above the physiological range at rest or during exertion. Meanwhile, in elderly patients and in those with underlying heart disease, decreased contractile reserve and systemic vascular resistance as well as abnormal high ventricular response can cause low-output HF, where the heart pumps blood at resting rate or at an effort below the physiological range $(4,5,6)$.

In clinical practice, CHF due to thyrotoxicosis is a rare entity. Even though exercise intolerance due to elevated cardiac output is the most common initial symptom in most patients, some patients might present with acute HF signs and symptoms as shown in our case (7). Also, patients may develop severe systolic dysfunction in the later stages of the disease if it is not treated. Although this condition is infrequent and commonly encountered in patients with pre-existing heart disease, our case has showed that it can develop in subjects without pre-existing heart disorder.

Sinus tachycardia and AF are the most common rhythm disorders, and they are usually reversible as a result of the treatment of thyrotoxicosis (8). The mechanism of arrhythmia caused by elevated thyroid hormone levels is multifactorial. Elevated thyroid hormone levels can alter $\beta 1$-adrenergic and M2-muscarinic receptors of the heart in patients with hyperthyroidism, which can result in an increase in sympathetic function and a decrease in atrial refractory period $(8,9)$. Additionally, high thyroid hormone can play a role in changing ionic channels, which can create a suitable substrate for AF formation $(8,9)$.

In patients with AF who are hyperthyroid at the time of diagnosis, the risks of a failure cardioversion increase

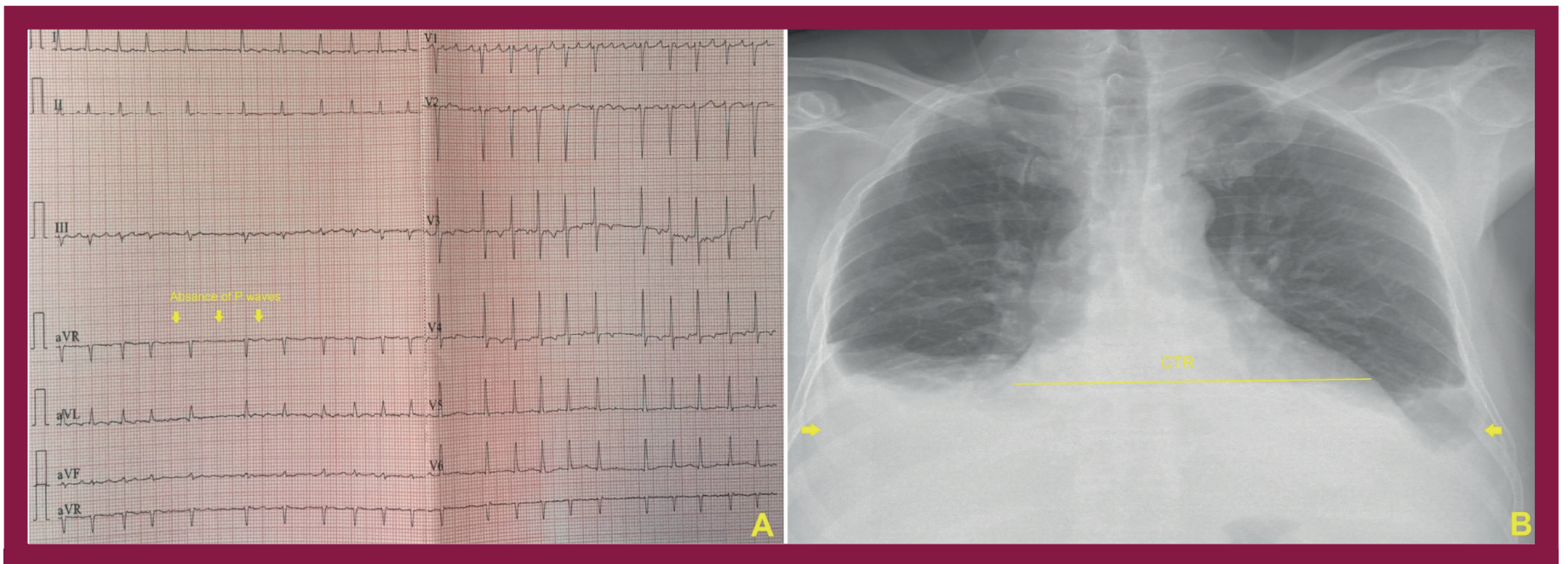

Figure 1. Electrocardiography and posterior-anterior chest scan of the patient. (A) Electrocardiography image showing atrial fibrillation. (B) Posterior-anterior chest scan image showing enlargement of the cardiothoracic ratio and bilateral pleural effusion 


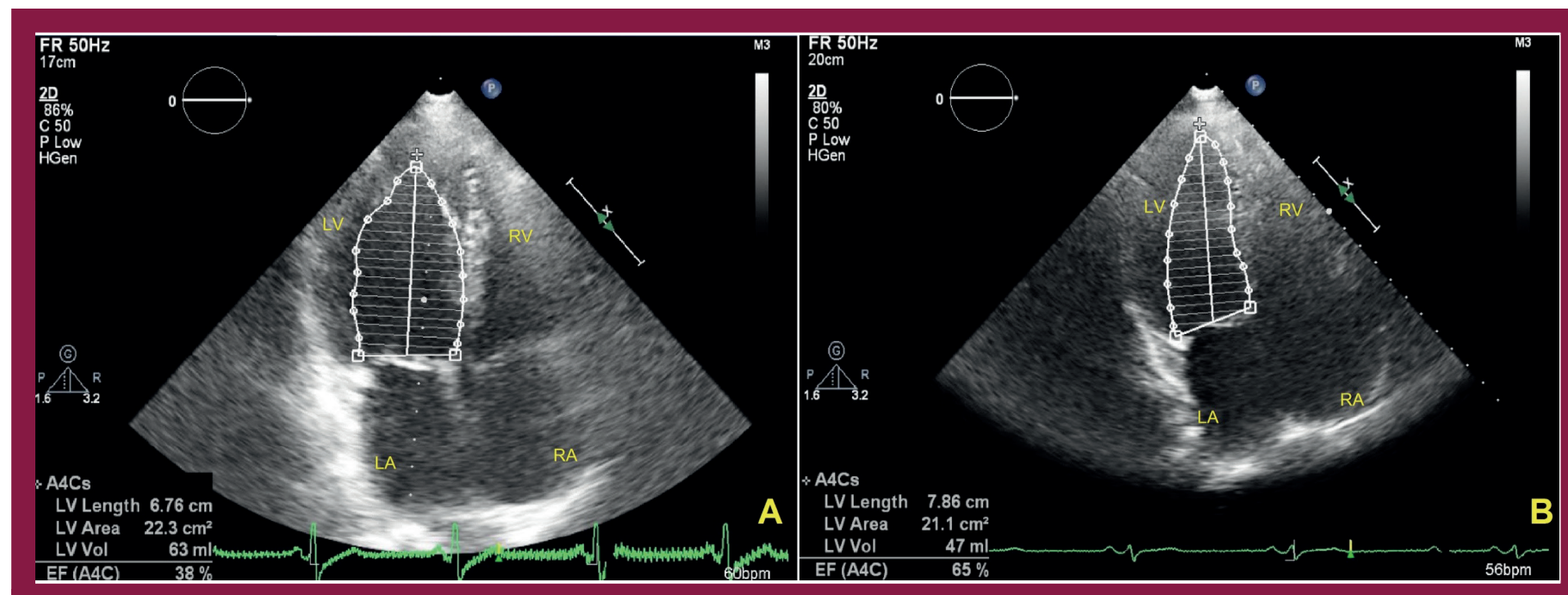

Figure 2. Transthoracic echocardiography of the patient. (A) Left ventricle ejection fraction was found to be $38 \%$ on one-month control according to the Simpson method. (B) Left ventricle ejection fraction was found to be $65 \%$ on six-month control according to the Simpson method

considerably (9). Thus, cardioversion may be an option for those who remain in $\mathrm{AF}$ after 8-10 weeks of remaining in a euthyroid state with anticoagulation for at least three weeks (9).

The mainstay of treatment in patients with HF reduced ejection fraction and AF is a combination of beta-blocker and anti-thyroid agents, such as PTU or methimazole $(2,9)$. Besides that, in the acute setting, amiodarone may be used due to the benefit of restoring normal sinus rhythm when paired with anti-thyroid drugs like PTU to reduce the risk of thyrotoxicosis worsening $(2,9)$. Lastly, patients who have $\mathrm{HF}$ findings should also be treated with ACE inhibitors, mineralocorticoid-receptor antagonists, and diuretics in addition to the aforementioned treatments (9).

\section{Conclusion}

In conclusion, in this case report, we have demonstrated that thyrotoxicosis can cause severe but reversible LV dysfunction in relatively young individuals without previous chronic disorder. Thus, routine monitoring of TSH levels should be performed in each patient presenting with acute $\mathrm{HF}$ to exclude thyrotoxicosis diagnosis.

\section{Ethics}

Informed Consent: Informed consent was obtained from the patient.

Peer-review: Externally and internally peer-reviewed.

\section{Authorship Contributions}

Concept: V.Ç., T.Ç., Design: M.S., A.L.O., Data Collection or Processing: V.Ç., T.Ç., M.S., Analysis or Interpretation: T.Ç., A.L.O., Literature Search:V.Ç., T.Ç., M.S., Writing:V.Ç., T.Ç.
Conflict of Interest: No conflict of interest was declared by the authors.

Financial Disclosure: The authors declared that this study received no financial support.

\section{References}

1. Janssen OE, Mann K, Erbel R. Das Herz bei endokrinen Erkrankungen [Endocrine disorders and the heart]. Internist (Berl). 2007;48:246-254. (German) [Crossref]

2. Osman F, Franklyn JA, Holder RL, Sheppard MC, Gammage MD. Cardiovascular manifestations of hyperthyroidism before and after antithyroid therapy: a matched case-control study. J Am Coll Cardiol. 2007;49:71-81. [Crossref]

3. Moura Neto A, Zantut-Wittmann DE. Abnormalities of Thyroid Hormone Metabolism during Systemic Illness: The Low T3 Syndrome in Different Clinical Settings. Int J Endocrinol. 2016;2016:2157583. [Crossref]

4. DeGroot WJ, Leonard JJ. Hyperthyroidism as a high cardiac output state. Am Heart J. 1970;79:265-275. [Crossref]

5. Niakara A, Bama A, Nebie LV. Signs and outcome of 61 cases of thyrotoxic heart disease. Tropical Cardiology. 2004;118:24-27. [Crossref]

6. Biondi B. Mechanisms in endocrinology: heart failure and thyroid dysfunction. Eur J Endocrinol. 2012;167:609-618. [Crossref]

7. Tsymbaliuk I,Unukovych D, Shvets N,Dinets A.Cardiovascular complications secondary to Graves' disease: a prospective study from Ukraine. PLoS One. 2015;10:e0122388. doi: 10.1371/journal.pone.0122388. [Crossref]

8. Klein I, Ojamaa K. Thyroid hormone and the cardiovascular system. N Engl J Med. 2001;344:501-509. [Crossref]

9. Reddy V, Taha W, Kundumadam S, Khan M. Atrial fibrillation and hyperthyroidism: A literature review. Indian Heart J. 2017;69:545-550. [Crossref] 